\title{
A Comprehensive Review on Animal Feed, Human Food and Industrial Application of Lanternfishes; from Prototypes to Products
}

\author{
Amir Reza Shaviklo ${ }^{1,2}$ (1) \\ ${ }^{1}$ Department of Animal Products Processing, Animal Science Research Institute of Iran, Agricultural Research, \\ Education and Extension Organization (AREEO), Karaj, Iran. \\ ${ }^{2}$ Yas Aquatic Protein Limited, Guilan Science and Technology Park (GSTP), The Ministry of Science, Research and \\ Technology, Rasht, Iran
}

\section{Article History}

Received 01 July 2020

Accepted 14 September 2020

First Online 17 September 2020

\section{Corresponding Author}

Tel.: +989121780143

E-mail: shaviklo@gmail.com

\section{Keywords}

Mesopelagic

Lanternfish

Myctophid

Animal Feed

Human Consumption

\begin{abstract}
Fishes of the family Myctophidae, commonly known as lanternfishes or myctophids, are a group of fishes with over 400 species. They are part of a large, underutilized biomass of mesopelagic fish species. Myctophids reserves in the world's oceans have been estimated at 550- 600 million tons. The largest lanternfishes reserves exist in the Arabian Sea and the Southern Ocean. Only a few myctophids species being edible $(<10$ species). They are a good source of proteins, amino acids, lipids, fatty acids, and minerals, which can be utilized in different industries. This review reports the prototypes and products made from myctophids and their properties based on published documents. Furthermore, distribution, biomass estimation, and fishing of myctophids and post-harvest changes and physicochemical properties of myctophids flesh are underlined. Challenges for further development of the myctophids industry and quality management of handling and processing of this resource are also addressed.
\end{abstract}

\section{Introduction}

The nutrition of many people in the world is dependent on aquatic sources. Increasing population and growing demand for aquatic proteins, particularly during the last 70 years, led to overexploitation of aquatic resources (FAO, 2020). However, fisheries and aquaculture are not able to meet the nutritional needs of the people. One way of dealing with this issue, at least to some extent, is to maximize the use of the low-value and underutilized resources such as myctophids fishes (Shahidi, 2006; Ababouch, 2012; Kim, 2014; Shaviklo \& Etemadian, 2019). Myctophids/ lanternfishes are a dominant component (about 75\%) of the mesopelagic fish fauna in the world's oceans (Gjøsæter, \& Kawaguchi, 1980; Gjøsæter, 1984; Sassa, Kawaguchi, Hirota, \& Ishida, 2004; Moser, \& Watson, 2006; Sassa, 2019). Staby, \& Salvanes, (2019) have identified 31 families of mesopelagic fish and described that typical morphology and taxonomy of mesopelagic fish differ between families (Figure 1). Myctophid's body color is mostly brownish-black. Gonichthys Centrohranchus, which live in relatively shallow depths, is silvery, and bluish iridescent scales cover Diaphus and Lobianchia. Myctophids range in sizes (adults) from about $2 \mathrm{~cm}$ to $30 \mathrm{~cm}$. (Nafpaktitis, 1982; FAO, 1997), and has a life cycle of 12 months (Gjøsæter, 1984; Sassa, Ohshimo, Tanaka, \& Tsukamoto, 2014). The majority of lanternfishes is not utilized as a human food because of high wax ester content in their lipid. Less than 10 of 405 myctophids species are edible (FAO, 2001; Lea, Nichols, \& Wilson, 2002). Figure 2, illustrates four edible myctophids species. The skinny cheek lanternfish, Benthosema pterotum, an edible species, is the largest myctophids reserve in the Arabian Sea (FAO, 2007) and in the East China Sea (Sassa, Takahashi, \& Tsukamoto, 2015). 


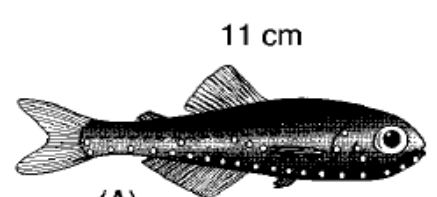

(A)

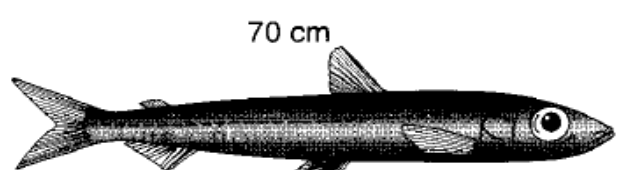

(C)

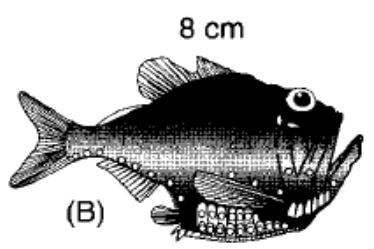

$7.6 \mathrm{~cm}$

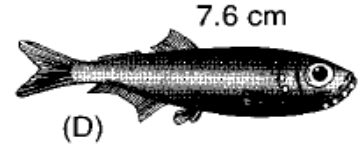

(D)

$30 \mathrm{~cm}$
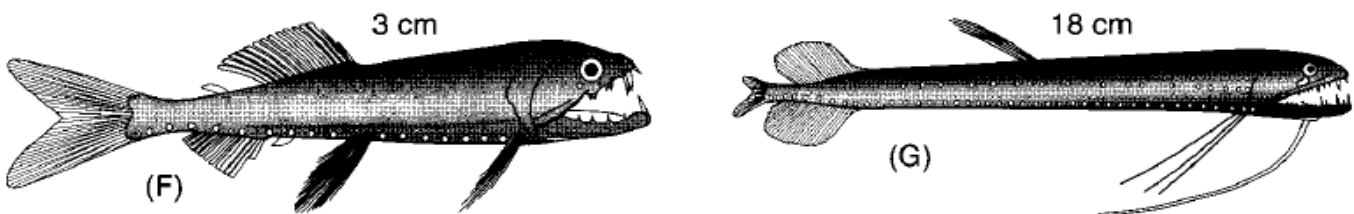

Figure 1. Mesopelagic fish. (A) Benthosema glaciale (Myctophidae). (B) Argyropelecus olfersii (Sternoptychidae) (C) Argentina silus (Argentinidae). (D) Maurolicus muelleri (Sternoptychidae). (E) Notolepis rissoi kroyeri (Paralepididae). (F) Astronesthes cyclophotus (Astronesthinae). (G) Bathophilu vaillanti (Melanostomiinae) (Adapted from Salvanes, \& Kristofersen, 2001).

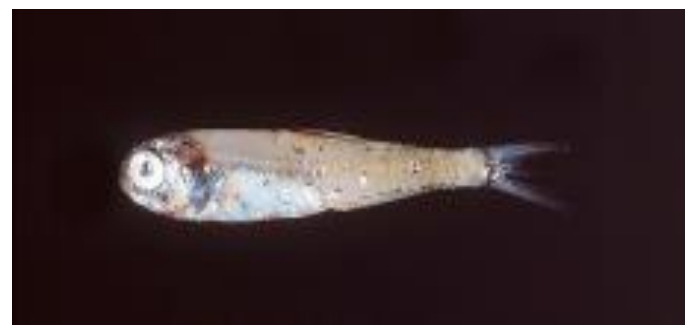

Benthosema pterotum

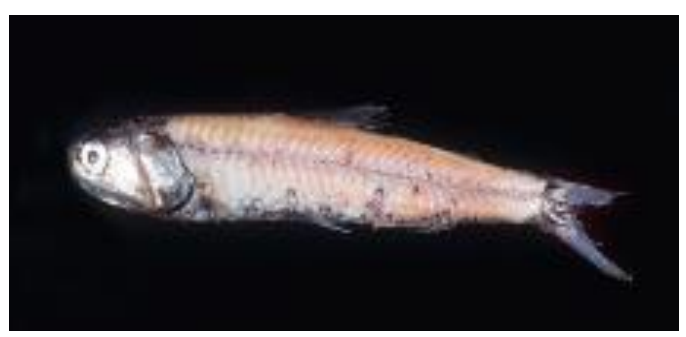

D. Watasei

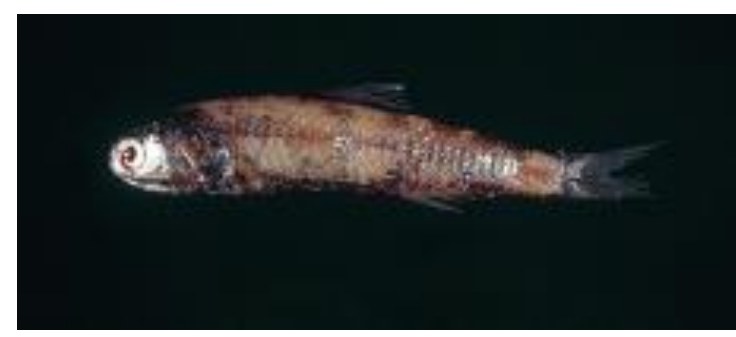

Diaphus coeruleus

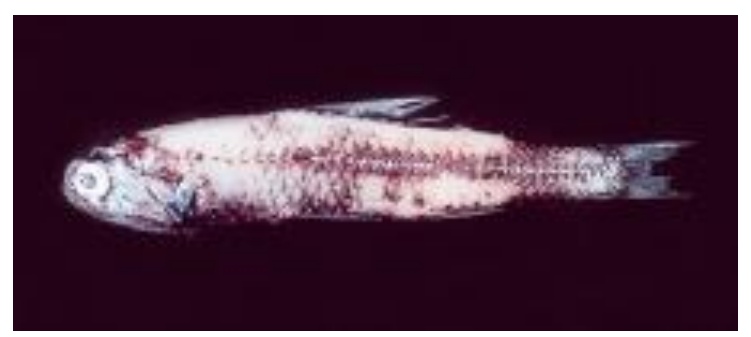

D. Suborbitalisi

Figure 2. Four edible myctophid species (Adapted from Wang, \& Chen, 2011).

Myctophids are nutritionally and economically important to world fisheries by providing raw material to the fishmeal industry and for human consumption (Hidalgo, \& Browman, 2019; Prellezo, 2019). There is a good potential for developing a variety of value-added products from myctophids such as fishmeal, fish oil, fish silage, mince, and surimi, fish protein isolate/ hydrolysate, as well as some other products like lubricating oil, cosmetics, and wax (Nair, Arul, Mathew, \& Gopakumar, 1983; Noguchi, 2004; Shaviklo, 2012a, b;
Shaviklo, \& Rafipour, 2013; Hidalgo, \& Browman, 2019; Prellezo, 2019). This review reports the distribution, biomass estimation, fishing and post-harvest changes of myctophids. Furthermore, physicochemical properties of myctophids flesh, prototypes and products made from myctophids and their quality properties are investigated. Possible risks related to lanternfish utilization for animal feed and human consumption, and challenges for further development of the myctophids industry are also addressed. 


\section{Distribution, Biomass Estimation and Fishing of Myctophids}

Myctophids are distributed worldwide, but the highest biomass is found in tropical and subtropical regions (Catul, Gauns, \& Karuppasamy, 2011; Olivar, Bode, Lo'pez-Pe'rez, Hulley, \& Herna'ndez-Leo'n, 2019). Currently, there is no large-scale fishing for myctophids, so fishing statistics and accurate biomass estimates are not available (Sassa, 2019). However, the amount of myctophids reserves in the world's seas and oceans was considered to be about 550- 600 million t (Gjøsæter, \& Kawaguchi, 1980). The myctophids biomass in the Arabian Sea was estimated at about 100 million $t$ (Gopakumar, Nair, Nair, Nair, Radhakrishnan, \& Nair, 1983; Gjøsæter 1984; Madhupratap, Nair, Gopalakrishnan, Haridas, Nair, Venugopal, \& Gauns, 2001). Recent estimates for the Oman Gulf were 2.3 million $t$ on average (Valinassab, 2005; Valinassab, Pierce, \& Johannesson, 2007) and in the Southern Ocean stock was estimated at 70-200 million $t$ out of the average 304 million $\mathrm{t}$ of total mesopelagic stocks (Kozlov, 1995; Pakhomov, Perissinotto, \& McQuaid, 1996) as cited by Catul et al., (2011).

There is only limited information on the commercial fishing of lanternfishes in the sub-Antarctic and the Gulf of Oman (Gopakumar et al., 1983; Gjøsæter, 1984; Moser, \& Watson, 2006; Valinassab et al., 2007; Prellezo, 2019). The majority of the myctophids catch was used as animal feed and crop fertilizers, not for direct human consumption (Lekshmy et al., 1983; Nair et al., 1983; Balu, \& Menon, 2006). Some myctophids species, e.g., Diaphus coeruleus, Gymnoscopelus nicholski, G. bolini, Diaphus watasei, Diaphus subortitalis, and Benthosema pterotum, were considered edible in the Southwest Indian Ocean and South Atlantic in the late 1970s (Nafpaktitis, 1982; Hulley, 1996; FAO, 1997), but there are no reports of human consumption of myctophids in India (FAO, 1997; Balu, \& Menon, 2006). However, industrial fishing of Benthosema pterotum in the Oman Sea begun in 1992, exclusively for fishmeal production in the Qeshm Island (located in the Persian Gulf, Iran) and the products (fishmeal and oil) are used locally or exported (Shaviklo, 2012a).

\section{Post-Harvest Quality Changes}

Few studies have reported postharvest quality changes of myctophids species. Haque, Peterson, Larsen, \& Opstvedt, (1981) reported 52.5 (mg 100 g-1) TVBN (Total Volatile Base Nitrogen), 27.4 (mg 100 g-1) TMA (trimethylamine), and 18.5 (mg $100 \mathrm{~g}-1$ ) TMAO (trimethylamine oxide), for defrosted Benthosema pterotum. Aftabsavar, (1992) studied quality changes of Benthosema pterotum landed at the port of Bandar Abbas (located in the Persian Gulf, Hormozgan province, Iran) during handling at ambient temperature $\left(23.6 \pm 0.28^{\circ} \mathrm{C}\right)$. TVBN, peroxide value (PV), total viable count, moisture, and $\mathrm{pH}$ of the samples were determined within the time intervals of $0,2,4,8,16$, and $24 \mathrm{~h}$ after capture (Table 1). After $24 \mathrm{~h}$, the changes in these parameters were $\mathrm{pH}$ 6.83-7.54, moisture $78-73 \%$, TVBN 20.2-263.2 (mg 100 g-1), PV 0-19.97 (meq/kg). After $24 \mathrm{~h}$, the total viable count was $2 \times 10^{12} \mathrm{CFU} / \mathrm{g}$. Accordingly, Moradi, (2001) reported $8 \mathrm{~h}$ shelflife for Benthosema pterotum when stored at ambient temperature $\left(23^{\circ} \mathrm{C}\right)$. When the ambient temperature during catching and handling of the fish is higher, this time interval will certainly decrease. Therefore,

Table 1. Changes of quality indexes of myctophid Benthosema pterotum, during 24 hours of handling from fishing ground to the landing site (Bandar Abbas, Iran), in ambient temperature $\left(23.6 \pm 0.28^{\circ} \mathrm{C}\right)$

\begin{tabular}{lccccc}
\hline $\begin{array}{l}\text { Time after } \\
\text { catching }\end{array}$ & $\begin{array}{c}\text { Moisture } \\
(\%)\end{array}$ & $\mathrm{pH}$ & $\begin{array}{c}\text { TVBN } \\
\text { (mg 100 g-1) }\end{array}$ & $\begin{array}{c}\text { Peroxid value } \\
\text { (meq/kg) }\end{array}$ & $\begin{array}{c}\text { Total count } \\
\text { (CFU/g) }\end{array}$ \\
\hline 0 & 78.0 & 6.83 & 20.2 & 0 & $4.9 \times 10$ \\
2 & 77.0 & 6.83 & 29.3 & 1.05 & $5.5 \times 10^{2}$ \\
4 & 76.2 & 6.84 & 36.1 & 2.92 & $2.3 \times 10^{3}$ \\
8 & 74.2 & 7.02 & 54.1 & 4.80 & $1.7 \times 10^{7}$ \\
16 & 74.0 & 7.32 & 138.9 & 9.31 & $8.7 \times 10^{10}$ \\
24 & 73.0 & 7.54 & 263.2 & 19.97 & $2.0 \times 10^{12}$ \\
\hline
\end{tabular}

Adapted from Aftabsavar, (1992). CFU: colony forming unit

Table 2. Microbiological quality of fresh myctophids landed in Kerala, India (CFU/g)

\begin{tabular}{lccc}
\hline & Myctophum & Myctophum & Diaphus \\
Microbiological parameters & obtusirostre & spinosum & $1.5 \times 10^{6}$ \\
\hline Aerobic plate count & $2.4 \times 10^{6}$ & $1.9 \times 10^{6}$ & $7.4 \times 10^{4}$ \\
Total Enterobacteriaceae & $8.9 \times 10^{2}$ & $5.7 \times 10^{4}$ & 0 \\
Total coliforms & 0 & $3.0 \times 10^{2}$ & 0 \\
Coagulase positive staphylococci & $8.4 \times 10^{3}$ & 0 & 0 \\
Fecal streptococci & 0 & 0 & 0 \\
\hline
\end{tabular}

Adapted from: Das et al., (2015), CFU: Colony forming unit 
myctophids species should be delivered to the fishmeal factory within $8 \mathrm{~h}$ of capture to develop good quality fishmeal. Therefore, it is necessary to investigate quality improvement of myctophids handling on board (Shaviklo, 2017).

Das, Jose Fernandez, \& Lalitha, (2015) examined the microbiological quality of three fresh myctophids fish species caught by deep-sea shrimp trawlers, operating off the southwest coast of Kerala, India (Table 2). The myctophids samples had an aerobic plate count ranging from $1.5 \times 10^{6}$ to $2.4 \times 10^{6} \mathrm{CFU} / \mathrm{g}$, while the total Enterobacteriaceae count ranged from $8.9 \times 10^{2}$ to $7.4 \times 10^{4} \mathrm{CFU} / g$. One sample (Myctophum obtusirostre) was found positive for coagulase staphylococci and the presence of coliform was detected in another sample (Myctophum spinosum).

Gopakumar et al. (1983) reported that the total viable count of frozen Benthosema pterotum was $2.9 \times 10^{3} \mathrm{CFU} / \mathrm{g}$. Coliforms, fecal streptococci, and coagulase-positive staphylococci were not observed in the samples of that study. From biological hazards point of view, no pathogenic microorganisms such as Coliforms, fecal Streptococcus, and Streptococcus coagulase-positive were identified in lanternfishes.

\section{Proximate Analysis}

In general, the biochemical composition of myctophids is in the range of other commercial marine fish species (Mahato, Baby, Sankar, Anandan, Vijayan, Ninan, \& Zynudheen, 2009; Jose Fernandez, Pradeep, Anandan, Zynudheen, \& Sankar, 2014; Navaneethan, Anandan, Jose Fernandez, Pradeep, Mathew, \& Sankar, 2014). The proximate composition of the lanternfish is varied because of the wide variety of species and the diet differences (Neighbors, \& Nafpaktitis, 1982; Lekshmy, Arul, Mathew, \& Gopakumar, 1983; Nair et al., 1983; Phleger, Nelson, Mooney, \& Nichols, 1999; Lea et al., 2002). The following ranges were reported for species of 10 genera: moisture $57.5-79.2 \%$, protein content $11.5-22.3 \%$, fat content $2.4-28.5 \%$, and ash 0.5 $3.6 \%$ have been reported (Table 3). Benthosema pterotum has $16.1 \%$ protein, $3.4 \%$ fat, $3.5 \%$ ash, and 77.2\% moisture content (Shaviklo, \& Rafipour, 2011). It contains 184.6 mg 100 g-1 sodium, 160.34 mg 100 g-1 potassium and $13.51 \mathrm{mg} 100 \mathrm{~g}-1$ calcium fresh weight (Gopakumar et al., 1983).

\section{Amino Acids Compositions}

No distinct difference exists between the amino acid composition of migratory and non-migratory myctophids (Seo et al., 1998). Jose Fernandez et al., (2014) reported that myctophids contain a good amount of protein and amino acids in comparison to common Indian commercial fishes.

The amino acid composition in samples from 11 species of myctophids is given in Table 4 . The results indicate small differences between the amino acid contents of the different species. The highest values for threonine and arginine were found in Benthosema fiburatum and Hygophum evermani, respectively. Benthosema pterotum contained the highest values of valine, methionine, phenylalanine, and histidine, while the highest level of isoleucine, leucine, and lysine was seen in Diaphus theta. Myctophum obtusirostre was recognized for the highest level of tryptophan (Seo et al., 1998).

Total essential amino acid contents the lanternfishes species are presented in Table 5 . Accordingly, Diafus effulgens has the highest total amino acid content $(52.0 \%)$ followed by Diafhus watasei (47.3\%), Diaphus theta (46.7\%) and Stenobrachius leucopsarus (45.7\%). The lowest total amino acid content was detected in Diaphus jenseni (37.9\%) followed by Benthosema pterotum (40.2\%). However, lanternfishes are rich in essential amino acids, showing similar values to those of other fish and shellfish species

Table 3. Proximate analysis (\%) of some myctophid species

\begin{tabular}{|c|c|c|c|c|c|}
\hline Species & Moisture & Protein & Fat & Ash & Reference \\
\hline Benthosema fibulatum & 76.6 & 18.6 & 3.2 & 3.1 & Navaneethan et al., (2014) \\
\hline Benthosema pterotum & 77.2 & 16.1 & 3.4 & 3.5 & Shaviklo, \& Rafipour, (2011), \\
\hline Ceratoscopelus warmingii & 64.9 & 11.5 & 20.6 & 2.3 & Gopakumar et al., (1983) \\
\hline Diaphus effulgens & 78.1 & 16.5 & 4.9 & 0.5 & Jose Fernandez et al., (2014) \\
\hline Diaphus gigas & 73.2 & 15.7 & 7.3 & 2.9 & Gopakumar et al., (1983) \\
\hline Diaphus Hudsoni & 74.1 & 14.4 & 7.7 & 3.6 & Jose Fernandez et al., (2014) \\
\hline Diaphus Jenseni & 76.9 & 18.8 & 3.4 & 3.0 & Navaneethan et al., (2014) \\
\hline Diaphus theta & 79.2 & 13.3 & 4.9 & 3.1 & Gopakumar et al., (1983) \\
\hline Diaphus watasei & 63.2 & 21.4 & 15.1 & 1.3 & Rajamoorthy et al., (2013) \\
\hline Lampadena luminosa & 66.6 & 11.5 & 19.8 & 1.8 & Gopakumar et al., (1983) \\
\hline Lampanyctus jordani & 75.2 & 13.4 & 9.3 & 2.4 & Gopakumar et al., (1983) \\
\hline Lampanyctus regalis & 73.1 & 12.1 & 13.4 & 1.9 & Gopakumar et al., (1983) \\
\hline Myctophum obtusirostris & 71.3 & 22.3 & 3.5 & 3.1 & Rajamoorthy et al., (2013) \\
\hline M. Spinosum & 77.6 & 19.3 & 2.4 & 2.3 & Navaneethan et al., (2014) \\
\hline Notoscopelus japonicus & 58.4 & 13.5 & 26.2 & 1.9 & Gopakumar et al., (1983) \\
\hline Symbolophorus californiensis & 57.5 & 12.3 & 28.5 & 2.0 & Gopakumar et al., (1983) \\
\hline Stenobrachius leucopsarus & 65.9 & 12.8 & 19.5 & 2.0 & Gopakumar et al., (1983) \\
\hline Stenobrachius nannochir & 67.2 & 12.5 & 18.0 & 1.9 & Gopakumar et al., (1983) \\
\hline
\end{tabular}


Table 4. Amino acid composition (g $100 \mathrm{~g}-1$ of protein) of some myctophid species

\begin{tabular}{|c|c|c|c|c|c|c|c|c|c|c|c|}
\hline Species & Threonine & Arginine & Valine & Methionine & Isoleuocine & Leucine & Lysin & Phenylalanine & Histidine & Tryptophan & Reference \\
\hline Benthosema fiburatum & 6.3 & 5.6 & 4.1 & 2.8 & 3.5 & 6.6 & 8.1 & 3.4 & 3.0 & 1.3 & Seo et al., (1998) \\
\hline Benthosema pterotum & 4.1 & 5.6 & 5.2 & 3.7 & 4.1 & 5.7 & 5.6 & 4.7 & 6.2 & 0.8 & Nair et al., (1983) \\
\hline Diaphus brachycephalus & 4.6 & 7.0 & 4.2 & 2.8 & 3.5 & 6.6 & 7.3 & 3.8 & 3.1 & 1.3 & Seo et al., (1998) \\
\hline Diaphus jenseni & 4.5 & 6.4 & 4.2 & 2.9 & 3.6 & 6.7 & 7.5 & 4.0 & 3.1 & 1.0 & Seo et al., (1998) \\
\hline Diaphus perspiciilatus & 3.9 & 5.8 & 4.4 & 2.8 & 3.6 & 6.8 & 7.7 & 3.4 & 3.1 & 1.3 & Seo et al., (1998) \\
\hline Diaphus theta & 4.0 & 5.4 & 4.7 & 3.3 & 4.4 & 7.7 & 8.1 & 4.8 & 3.0 & 1.3 & Seo et al., (1998) \\
\hline Hygophum evermani & 1.4 & 7.7 & 4.9 & 3.3 & 1.4 & 7.1 & 8.0 & 3.8 & 3.0 & 1.2 & Seo et al., (1998) \\
\hline Myctophum asperum & 3.9 & 7.3 & 4.7 & 3.2 & 1.4 & 7.1 & 7.9 & 3.7 & 2.9 & 1.2 & Seo et al., (1998) \\
\hline Myctophum obtusirostre & 3.4 & 4.8 & 4.5 & 2.0 & 3.4 & 7.3 & 8.0 & 3.8 & 3.1 & 1.4 & Seo et al., (1998) \\
\hline Stenobrachius nannochir & 3.6 & 5.0 & 4.0 & 1.5 & 4.2 & 7.3 & 7.7 & 5.3 & 3.3 & 1.2 & Seo et al., (1998) \\
\hline Stenobrachius Ieucopsarus & 4.1 & 5.9 & 4.5 & 3.0 & 4.0 & 7.4 & 7.9 & 4.7 & 2.9 & 1.3 & Seo et al., (1998) \\
\hline
\end{tabular}


like oil sardines (Jose Fernandez et al., 2014) and blue crab (Aygul and Mehmet, 2008). The total amino acid content of Benthosema pterotum is greater than that of the deep-sea lobster, Indian white shrimp, and reef cod (Gopakumar, 1997) but comparable to oil sardine and blue crab (Aygul and Mehmet, 2008; Jose Fernandez et al., 2014).

\section{Lipid Class, Fatty Acid Composition and Risks of Wax Ester Levels}

As presented in Table 6, myctophids are grouped; 1) based on the concentration of lipid and wax (Noguchi, 2004); 2) based on lipid composition (Seo, Endo, Fujimoto, Watanabe, \& Kawaguchi, 1996); and 3) based on the migratory behavior (Lea et al., 2002; Seo et al., 1996; 1998). Stenobrachius leucopsarus, Stenobrachius nannochir, and Lampanyctus regalis are high lipids and high wax myctophids. Species showing diel vertical migration are rich in triacylglycerides or phospholipids but species not showing diel vertical migration are rich in wax esters (Table 6). The concentration of wax ester in myctophids species differs from less than $1 \%$ of the total lipid content in Benthosema pterotum (El-Mowafi, Nanton, \& Berntssen, 2010) to 86.2-90.5\% of the total lipid in Electrona Antarctica (Phleger et al., 1999). However, the effects of season and geographical location on wax ester levels in lanternfish still need to be investigated (Saito, \& Murata, 1996; Seo et al., 1998). It is believed that triglycerides serve as an energy store and wax esters are used for buoyancy in myctophids species (Gopakumar et al., 1983; Noguchi, 2004).
Commercial fish oil is typically dominated by triacylglycerol (>90\% lipid) and contains little phospholipid. Phosphatidylcholine was the prevailing phospholipid (13\% of total lipid) in lanternfish Benthosema pterotum with a smaller amount of phosphatidylserine /phosphatidylinositol at $1.7 \%$ (of total lipid) (El-Mowafi et al., 2010). Seo et al., (1996) investigated lipids in 20 myctophids fish species harvested from the western subarctic and the tropical Pacific Ocean. The lipid content of myctophids fishes ranged from 0.5 to $21.7 \%$ and these fishes were classified into three groups by lipid compound level: five triglyceride-rich species, 3 wax ester-rich species and 12 phospholipid-rich species. No fish rich in both wax esters and triglycerides was observed in their study. The wax ester-rich and triglyceride-rich groups were in the western subarctic Pacific, while the phospholipid-rich group with low-lipid content was in the tropics. More than $90 \%$ of total lipids in Lampanyctus regalis, Stenobrachius leucopsarus, and Stenobrachius nannochir, were wax esters with 30 to 44 carbon chain lengths. The lipid analysis noted that wax esters are rich in non-migratory or partly migratory myctophids species (Seo et al., 1996).

The amount of fat in most species of lanternfish is high except for species like Benthosema pterotum (3.4\%). Triglycerides are the major fat type, but some species have wax esters. Several species, e.g., Stenobrachius leucopsarus, Stenobrachius nannochir, and Lampanyctus regalis, are rich in wax (Saito, \& Murata, 1996). The fat content of all myctophids species has a large number of neutral deposit fats (89.5 to

Table 5. Comparison of total essential amino acid content (g $100 \mathrm{~g}-1$ of protein) of myctophids with other commercially important fish and shellfish species

\begin{tabular}{lcc}
\hline Species & Total amino acid content & Reference \\
\hline Myctophid species & & Gopakumar, (1997) \\
Benthosema fiburatum & 44.7 & Nair et al., (1983) \\
Benthosema pterotum & 40.2 & Jose Fernandez et al., (2014) \\
Diaphus effulgens & 52.0 & Jose Fernandez et al., (2014) \\
Diaphus hudsoni & 41.9 & Seo et al., (1998) \\
Diaphus perspiciilatus & 43.7 & Seo et al., (1998) \\
Diaphus jenseni & 37.9 & Seo et al., (1998) \\
Diaphus brachycephalus & 44.2 & Gopakumar, (1997) \\
Diaphus theta & 46.7 & Rajamoorthy et al., (2013) \\
Diaphus watasei & 47.3 & Gopakumar, (1997) \\
Hygophum evermani & 41.8 & Gopakumar, (1997) \\
Myctophum asperum & 43.3 & Rajamoorthy et al., (2013) \\
Myctophum obtusirostre & 43.2 & \\
& 77 & Seo et al., (1998) \\
Stenobrachius nannochir & 43.1 & Seo et al., (1998) \\
Stenobrachius leucopsarus & 45.7 & \\
Other fish and shellfish species & & Gopakumar, (1997) \\
Reef cod (Epinepheius areolatus) & 36.7 & Gopakumar, (1997) \\
Deep sea lobster (Puerulus sewelli) & 26.7 & Gopakumar, (1997) \\
Indian white shrimp (Fenneropenaeus indicus) & 36.8 & Aygul and Mehmet, (2008) \\
Blue crab (Callinectes sapidus) & 45.0 & Jose Fernandez et al., (2014) \\
Oil sardine (Sardineila longiceps) & 55.8 & Jose Fernandez et al., (2014) \\
Flathead grey mullet (Mugil cephalus) & Jose Fernandez et al., (2014) \\
Indian mackerel (Rastrelliger kanagurta) & 55.2 &
\end{tabular}


Table 6. Classification of myctophids based on lipid characteristics (cited by Mahato et al., 2009)

\begin{tabular}{|c|c|}
\hline Category & Reference/Species \\
\hline Based on lipid composition & (Seo et al., (1996) \\
\hline Myctophid rich in phospholipids & $\begin{array}{c}\text { Diaphus perspicillatus, Diaphus jenseni, Symbolophorus } \\
\text { evermani }\end{array}$ \\
\hline Myctophid rich in triacylglyceride & Diaphus gigas, Lampanyctus Jordani, Diaphus theta \\
\hline Myctophid rich in wax ester & $\begin{array}{l}\text { Stenobrachius leucopsarus, Stenobrachius nannochir, } \\
\text { Lampanyctus regalis }\end{array}$ \\
\hline Based on the concentration of lipid and wax & Noguchi, (2004) \\
\hline Myctophid with low lipid and low wax & Diaphus gigas, Diaphus theta, Lampanyctus jordani \\
\hline Myctophid with high lipid and low wax & $\begin{array}{c}\text { Ceratoscopelus warmingii, Lamedana ILiminosa, Notoscopelus } \\
\text { Japonicus, Symbolophorus californiensis }\end{array}$ \\
\hline Myctophid with high lipid and high wax & $\begin{array}{c}\text { Stenobrachius leucopsarus, Lampanyctus regalis, Stenobrachius } \\
\text { nannochir }\end{array}$ \\
\hline Based on migratory behavior & Lea et al., (2002); Seo et al., (1996); Saito and Murata, (1996) \\
\hline $\begin{array}{l}\text { Species showing diel vertical migration, rich in } \\
\text { triacylglycerides }\end{array}$ & All triacylglyceride rich species except: Lampanyctus Jordani \\
\hline Species showing diel vertical migration, rich in phospholipids & $\begin{array}{c}\text { Diaphus perspicillatus, Diaphus Jenseni, Symbolophorus } \\
\text { evermani. }\end{array}$ \\
\hline Species not showing diel vertical migration, rich in wax ester & $\begin{array}{c}\text { Stenobrachius leucopsarus, Stenobrachius nannochir, } \\
\text { Lampanyctus regalis }\end{array}$ \\
\hline
\end{tabular}

98.5\%) and a small number of polar fats (1.5 to $10.5 \%$ ) as part of total amount of fats. Neutral deposit fats, such as triglycerides, range from $70.7 \%$ to $92.3 \%$ and wax esters range from $85.6 \%$ to $89.4 \%$. Sterols vary from $1.3 \%$ to $7.8 \%$, and most of them are cholesterol (Saito, \& Murata, 1998).

In myctophids, the total monoene fatty acid ranges from $65.4-87.7 \%$ in wax ester rich species, while in triacylglycerols rich species it ranges from 42.1 to $66.5 \%$ of the total fatty acids. Monoenoic acids such as $18: 1$ and 22:1 are the main fatty acids in the lanternfishes containing triacylglycerols as the major constituent, while in wax ester rich species $18: \ln -9$ and $20: \ln -11$ are the major fatty acid components. Both the wax ester and the triacylglycerol species contain lower levels of polyunsaturated fatty acid (PUFA) such as EPA (20:5n-3) and DHA (22:6n-3). The concentrations of essential fatty acids like 20:5n-3 and 22:6n-3 is somewhat higher in triacylglyceride rich species (Phleger, Nichols, \& Virtue, 1991; Seo et al., 1996; Saito et al., 1996; 1998; Phleger et al., 1999; Lea et al., 2002). Oleic acid (18: In-9) is the major fatty acid in almost all species but in species rich in phospholipids, palmitic acid (16:0) and docosahexenoic acid (22:6n-3) are the predominant fatty acids (Seo et al., 1996). Among the wax ester rich species, wax esters consisted mainly of 30 to 44 carbon chain lengths, and the wax ester composition varied from species to species. For example, the wax of Lampanyctus regalis was composed mainly of 40 and 42 carbon chain lengths while in Stenobrachius leucopsarus and Stenobrachius nannochir it was 34 and 32 to 40, respectively (Seo et al., 1998).

Nutritional profiles showed appropriate amounts of fatty acids (EPA and DHA) in myctophids, compared to other fishes (Jose Fernandez et al., 2014). The amino acid pattern of Benthosema pterotum is in the range of FAO/WHO (1991) scoring pattern. The fatty acid composition of 3 edible lanternfish samples is presented in Table 7. The composition of the fatty acids in myctophids oil is similar to that of oil produced from other fish species (Nair et al., 1983). Wax esters in Benthosema pterotum body and its meal and oil were not identified (Chai, Chan, Chen, Wu, \& Shiau, 2012). Compared to the Diaphus Watasei and Diaphus Suborbitalisi, Benthosema pterotum has the highest level of PUFA, EPA, and DHA. The content of total saturated fatty acids and total polyunsaturated fatty acids in Benthosema pterotum are $37.0 \%$ and $35.1 \%$, respectively and the amount of omega- 6 and omega- 3 fatty acids is $5.4 \%$ and $28.5 \%$, respectively. Palmitic acid (C16: 0$)$, is the prevailing fatty acid (21.4\%) among the saturated fatty acids, and stearic acid (C18: 0 ) is in the next position (5.9\%) (Table 7).

Oleic acid (C18: 1 n9) with $10.6 \%$ and palmitoleic acid (C16: 1n9) with $7.4 \%$ have the highest level of monounsaturated fatty acids. DHA and EPA levels in the Benthosema pterotum are $15.9 \%$ and $8.3 \%$, respectively, of the total fatty acids of this species. The percentage of EPA+DHA in Benthosema pterotum (24.2\%) is higher than typical North Atlantic fish oil and approaching levels of South American fish oil. EPA levels are usually equal to or higher than DHA in most commercial fish oil. The total n-6 fatty acid content is low in commercial fish oil $(<5 \%)$ and is relatively low in Benthosema pterotum (5.4\%). The arachidonic acid content $(20: 4 n-6)$ at $2.1 \%$ is slightly higher than most typical commercial fish oil ( $1 \%$ or less) (Koizumi, Hiratsuka, \& Saito 2014). Increased saturated fatty acids in dietary oil hurt lipid digestibility in fish (Seo et al., 1996). Saturated fatty acids in fish oil typically range from 20 to $30 \%$ with North Atlantic at the lower and South American at the higher end. Lanternfishes have a relatively high saturated fatty acid level of $37 \%$ compared to these fish oils but is lower than palm oil 
Table 7. Fatty acid composition (\% total fatty acids) of 3 edible lantern fishes

\begin{tabular}{|c|c|c|c|c|}
\hline Common name & Fatty acids & $\begin{array}{c}\text { Benthosema } \\
\text { pterotum }\end{array}$ & $\begin{array}{l}\text { Diaphus } \\
\text { watasei }\end{array}$ & $\begin{array}{c}\text { Diaphus } \\
\text { suborbitalisi }\end{array}$ \\
\hline & Total saturated & 37.0 & 30.9 & 34.2 \\
\hline Myristic acid & $14: 0$ & 5.0 & 2.8 & 3.6 \\
\hline Pentadecanoic acid & $15: 0$ & 0.9 & 0.2 & 0.5 \\
\hline Palmitic acid & $16: 0$ & 21.4 & 20.3 & 22.2 \\
\hline Margaric acid & $17: 0$ & 0.9 & 0.3 & 0.7 \\
\hline Stearic acid & $18: 0$ & 5.9 & 6.0 & 5.1 \\
\hline Nonadecylic acid & 19:0 & 0.4 & 0.1 & 0.2 \\
\hline Arachidic acid & $20: 0$ & 0.4 & 0.3 & 0.4 \\
\hline Behenic acid & $22: 0$ & 0.3 & 0.1 & 0.2 \\
\hline \multirow[t]{2}{*}{ Tetracosanoic acid } & $24: 0$ & 0.5 & 0.1 & 0.2 \\
\hline & Total monoenoic & 26.5 & 52.9 & 38.0 \\
\hline 5Z-hexadecenoic acid & $16: 1 n-11$ & 0.0 & 0.2 & 0.0 \\
\hline Palmitoleic acid & $16: 1 n-7$ & 7.4 & 3.6 & 6.9 \\
\hline Margaroleic acid & $17: 1 n-8$ & 0.6 & 0.5 & 0.6 \\
\hline Oleic acid & $18: 1 n-9$ & 10.6 & 38.2 & 16.0 \\
\hline Cis-vaccenic acid & $18: 1 n-7$ & 2.8 & 2.8 & 2.7 \\
\hline Gadoleic acid & $20: 1 n-11$ & 0.3 & 0.8 & 0.5 \\
\hline Eicosenoic acid & $20: 1 n-9$ & 1.1 & 3.3 & 2.9 \\
\hline Paullinic acid & $20: 1 n-7$ & 0.3 & 0.2 & 0.2 \\
\hline Cetoleic acid & $22: 1 n-11$ & 1.4 & 1.5 & 5.3 \\
\hline Erucic acid & $22: 1 n-9$ & 0.2 & 0.3 & 0.5 \\
\hline 15-docosenoic acid & $22: 1 n-7$ & 0.2 & 0.1 & 0.2 \\
\hline \multirow[t]{3}{*}{ Nervonic acid } & $24: 1 n-9$ & 1.1 & 0.7 & 1.5 \\
\hline & Total PUFA & 35.1 & 15.9 & 26.7 \\
\hline & Total $n-4$ polyenoic & 1.2 & 0.6 & 1.4 \\
\hline Palmitolinoleic acid & $16: 2 n-4,7$ & 1.1 & 0.5 & 1.2 \\
\hline 6,9,12-hexadecatrienoic acid & $16: 3 n-4$ & 0.0 & 0.0 & 0.0 \\
\hline $6,9,12,15$-hexadecatetraenoic acid & $16: 4 n-1$ & 0.0 & 0.0 & 0.0 \\
\hline \multirow[t]{2}{*}{$9,12,15,17$-octadecatetraenoic acid } & $18: 4 n-1$ & 0.0 & 0.1 & 0.2 \\
\hline & Total $n-6$ polyenoic & 5.4 & 2.6 & 3.6 \\
\hline Linoelaidic acid & $18: 2 n-6,9$ & 1.3 & 0.7 & 0.9 \\
\hline 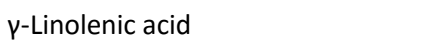 & $18: 3 n-6,9,12$ & 0.1 & 0.2 & 0.2 \\
\hline 11,14-eicosadienoic acid & $20: 2 n-6,9$ & 0.2 & 0.3 & 0.3 \\
\hline Dihomo-gamma-linolenic & $20: 3 n-6$ & 0.2 & 0.0 & 0.0 \\
\hline Arachidonic acid & $20: 4 n-6$ & 2.1 & 0.9 & 1.4 \\
\hline 13,16-docosadienoic acid & $22: 2 n-6,9$ & 0.0 & 0.0 & 0.0 \\
\hline $7 Z, 13 Z, 16 Z$-docosatrienoic acid & $22: 3 n-6,9,12$ & 0.3 & 0.2 & 0.3 \\
\hline Adrenic Acid & $22: 4 n-6$ & 0.2 & 0.1 & 0.1 \\
\hline \multirow[t]{2}{*}{ Docosapentaenoic acid } & $22: 5 n-6$ & 0.9 & 0.3 & 0.4 \\
\hline & Total $n-3$ polyenoic & 28.5 & 12.6 & 21.8 \\
\hline Linolenic acid & $18: 3 n-3$ & 1.1 & 0.3 & 0.5 \\
\hline Octadecatetraenoic acid & $18: 4 n-3$ & 1.2 & 0.2 & 0.6 \\
\hline Eicosatrienoic acid & $20: 3 n-3$ & 0.1 & 0.2 & 0.0 \\
\hline Eicosatetraenoic acid & $20: 4 n-3$ & 0.6 & 0.5 & 0.7 \\
\hline Eicosapentaenoic acid (EPA) & $20: 5 n-3$ & 8.3 & 3.5 & 6.6 \\
\hline \multirow[t]{2}{*}{$8,12,16,19$-docosatetraenoic acid } & $22: 4 n-3$ & 0.0 & 0. & 0.0 \\
\hline & & & 0 & \\
\hline Docosapentaenoic acid & $22: 5 n-3$ & 1.3 & 1.0 & 1.1 \\
\hline \multirow[t]{4}{*}{ Docosahexaenoic acid (DHA) } & $22: 6 n-3$ & 15.9 & 6.9 & 12.2 \\
\hline & Total fatty acids & 98.6 & 99.7 & 98.9 \\
\hline & Actual EPA levels (mg $100 \mathrm{~g}-1$ ) & 341.3 & 402.2 & 396.6 \\
\hline & Actual DHA levels (mg $100 \mathrm{~g}-1)$ & 652.1 & 783.5 & 734.4 \\
\hline
\end{tabular}

(49\%). This should be considered when the utilization of lanternfish oil (Saito, \& Murata, 1996).

The presence of large quantities of wax esters (82.91\% of total lipids) in some myctophid fishes (Triphoturus mexicanus, Lampanyctus ritteri, and Stenobrachius leucopsarus) was first identified by Nevenzel, Rodegker, Stephen, \& Kayama, (1969). Similar high wax ester levels were detected in other myctophids species including $L$. regalis and S. nannochir (Saito, \&
Murata, 1996). In Neighbor's (1988) study for lipid assessment of 41 lanternfishe species, nine species contained greater percentages of wax esters than triacylglycerols. In Electrona Antarctica the wax esters were $45-52 \%$ of total lipid reported by Reinhardst, \& Van Vleet, (1986).

Studies reported the toxicity of wax esters for animal feed (Haque et al., 1981; Lekshmy et al., 1983). Mori, Saito, Nakanishi, Miyazawa, \& Hashimoto, (1966) 
Table 8. Proximate analysis (\%) of Benthosema pterotum meal and 5 other fish meals

\begin{tabular}{lccccc}
\hline Fish meal & Moisture & Protein & Fat & Ash & Source \\
\hline Anchovy (Engraulis ringens) & 7.7 & 66.7 & 11.1 & 16.3 & El-Mowafi et al., (2010) \\
Blue whiting (Micromesistius poutassou) & 8.8 & 68.8 & 8.8 & 16.0 & El-Mowafi et al., (2010) \\
Capelin (Mallotus villosus) & 7.0 & 96.6 & 11.6 & 9.1 & Ariyawansa, (2000) \\
Herring (Clupea harengus) & 8.0 & 72.0 & 9.0 & 10.0 & FAO, (1986) \\
Kilka fish (Family Clupeidae) & 7.2 & 64.0 & 7.8 & 13.3 & Azimi et al., (2011) \\
Myctophid (Benthosema pterotum) & 6.1 & 68.5 & 6.2 & 17.9 & Nair et al., (1983) \\
\hline
\end{tabular}

Table 9. The amino acid composition of freeze dried Benthosema pterotum, blue whiting and anchovy fishmeals

\begin{tabular}{|c|c|c|c|c|}
\hline Amino acids (g/kg) & $\begin{array}{l}\text { Freeze dried } B . \\
\text { pterotum, }\end{array}$ & B. pterotum meal & Blue whiting meal & Anchovy fish meal \\
\hline Methionine & 18.1 & 18.6 & 20.2 & 18.5 \\
\hline Cystine & 9.2 & 9.5 & 7.8 & 6.1 \\
\hline Lysine & 50.4 & 51.9 & 57.6 & 53.3 \\
\hline Tryptophan & 6.7 & 6.9 & 7.3 & $\mathrm{n} / \mathrm{a}$ \\
\hline Threonine & 27.5 & 28.3 & 29.0 & 28.3 \\
\hline Isoleucin & 24.0 & 24.7 & 30.5 & 30.2 \\
\hline Histidine & 14.0 & 14.4 & 13.8 & 21.4 \\
\hline Valine & 29.3 & 30.2 & 36.0 & 35.5 \\
\hline Leucine & 46.3 & 47.7 & 52.0 & 50.0 \\
\hline Arginine & 36.4 & 37.5 & 42.6 & 37.9 \\
\hline Phenyl alanine & 24.8 & 35.5 & 27.1 & 26.6 \\
\hline Tyrosin & 20.4 & 21.0 & 22.0 & 20.8 \\
\hline Asparatic Acid & 59.1 & 60.8 & & \\
\hline Glutamic Acid & 88.2 & 90.8 & 100.3 & 87.8 \\
\hline Glycine & 34.2 & 35.2 & 44.9 & 41.2 \\
\hline Hydroxy proline & 3.3 & 3.4 & 4.5 & 4.9 \\
\hline Ornithine & $<0.1$ & $<0.1$ & 0.3 & $<0.1$ \\
\hline Proline & 24.6 & 25.3 & 27.4 & 27.8 \\
\hline Serine & 27.4 & 28.2 & 31.2 & 26.6 \\
\hline Alanine & 39.5 & 40.7 & 44.0 & 43.0 \\
\hline
\end{tabular}

Adapted from: El-Mowafi et al., 2010

reported that rats fed with diets containing $1.5 \%$ waxrich fish oil suffered from indigestion and diarrhea for several days and died within 10 days. However, high levels of wax ester, i.e. over $50 \%$ of lipid, can be a hazard and may lead to reduced digestibility and growth as Oxley, Bogevik, Henderson, Waagbo, Tocher, \& Olsen, (2009) found in Atlantic salmon. The wax esters also are harmful for human (Balu, \& Menon, 2006). Since most species of lanternfishes contain a high level of wax esters, they are not suitable for direct human consumption (Shaviklo, 2017). The species of myctophids are free from heavy metals such as mercury, lead, arsenic, and cadmium (Teutscher, 2001) and the organic pollutants such as PCB and PCDD are well within the limits recommended by international standards (EIMowafi et al., 2010).

\section{Myctophids Meal and Oil for Animal Feed}

Nair et al., (1983) and Haque et al., (1981), reported fishmeal production from Benthosema pterotum with a yield of $20 \%$ and a 12 -month shelf life at ambient temperature $\left(28 \pm 2^{\circ} \mathrm{C}\right)$. The yield of fishmeal production from Diaphus watasei was $16.7 \%$ as reported by Boopendranath, Vijayan, Remesan, Anandan, Ninan, et al., (2012). It contained 4.3\% moisture, $64.8 \%$ protein, $28.7 \%$ fat and $8.2 \%$ ash.

Table 8, shows the proximate analysis of fishmeals made from the Benthosema pterotum and five other commercial fishes. The Benthosema pterotum meal contained $68.5 \%$ protein, $6.2 \%$ fat, $6.1 \%$ moisture, and $17.9 \%$ ash. Analytical data (Table 8) indicate that fishmeal from lanternfish is very similar to anchovy meal and blue whiting meal, better than Kilka fishmeal (Caspian Sea anchovy) and lower than herring meal, from the quality point of view. Haque et al., (1981) stated that the quality of the Benthosema pterotum meal was similar to the capelin meal.

Table 9, presents the amino acid composition of freeze-dried fish and fishmeal made from Benthosema pterotum, blue whiting, and anchovy. Benthosema pterotum meal contained more cysteine and phenylalanine than the other two fishmeals. However, lysine, isoleucine, valine, leucine, glycine, 
hydroxyproline, and proline amino acids were the least in Benthosema pterotum (El-Mowafi et al., 2010). Noguchi, (2004) reported the production of fish feed from Diaphus theta and Stenobrachius nannochir with $2 \%$ wax.

The use of myctophids meal in broiler diets has shown the absorption of amino acids from $92 \%$ for arginine to $73 \%$ for hydroxyproline (Haque et al., 1981). A comparative study of the protein efficiency ratio of myctophids meal, with casein as the standard, confirmed the higher quality of the myctophids meal for amino acid composition. The growth rate and efficiency ratio of myctophids protein were better than those found for casein. Hence, the myctophids meal was recommended for the formulation of animal and aqua feeds as a good protein supplement (Nair et al., 1983). The amino acid score for both meal and hydrolysate was higher than the values set by FAO/WHO for all essential amino acids except tryptophan (Nair et al., 1983).

A growth trial carried out by Haque et al., (1981), using white Plymouth chicks, found no significant differences between myctophids meal and capelin meal with regard to feed consumption, growth rate or efficiency of feed utilization ( $k$ feed/ kg live weight gain). However, using both fishmeals together improved the efficiency of feed utilization compared with soybean meal. Myctophids meal did not contain injurious amount of wax esters.

To determine the quality of myctophids meal, a study comparing Benthosema pterotum meal and anchovy meal imported from Peru was conducted using farmed poultry in Iran. Results showed no significant difference in the mean weight and feed conversion ratio between groups fed with the myctophids meal and those fed with the imported Anchovy meal. In general, the results of this study concluded that it is possible to replace anchovy fishmeal with myctophids meal in a feed of broiler chickens (Kiaei, Sanei, \& Farkhori, 2001).

A study done in India on the suitability of fishmeal prepared from Diaphus watasei as a protein supplement in animal feeds indicated that Albino rats fed with myctophids meals had better growth compared to standard casein feed. The average protein efficiency ratio and feed conversion ratio for the myctophids mealbased feed were 1.0 and 7.4, respectively, and that of casein-based control feed were 0.7 and 9.1, indicating the superior quality of the myctophids meal feed (Boopendranath et al., 2012).

The yield of oil from Diaphus watasei samples obtained during different seasons ranged from $5.9 \%$ to $8.34 \%$. The oil had an iodine value of 91.61, a saponification value of 119.75 , a specific gravity of 0.906 , a refractive index of 1.47 , and a viscosity of 58.9 $\mathrm{CP}$ at $23^{\circ} \mathrm{C}$. This oil contained $34.71 \%$ saturated fatty acids (SFA), $57.51 \%$ monounsaturated fatty acids (MUFA), and $2.41 \%$ poly-unsaturated fatty acids (PUFA). The physical properties of the myctophids oil indicated its suitability for industrial applications (Boopendranath et al., 2012). Bahri et al., (2015) studied fatty acid profiles of Benthosema pterotum and Sardinella Sinensis and reported that both species had high levels of omega- 3 fatty acids, can be used as sources for the food industry and the production of omega-3-enriched foods or supplements.

\section{Myctophids Food Products}

The feasibility of manufacturing human food products from myctophids fishes have been carried out in few countries including Iran. The results of these studies are reviewed below.

\section{Myctophids Drying and Smocking}

Dry fish is a commercially important product. Generally, small and medium-sized fish are dried as such, or after curing with salt and seasoning, and have high demand especially in Asian markets. Balu, \& Menon, (2006) reported the smoking of two myctophids species, Gymnoscopelus bolini, and Gymnoscopelus nicholsi, for human consumption in the 1970s. Production of dried fish from lanternfishes with a shelflife of more than 6 months, when stored at ambient temperature $\left(28 \pm 2^{\circ} \mathrm{C}\right)$, was reported by Nair et al. (1983). Teutscher, (2001) developed a cooked and dried fish from myctophids. Dry fish was prepared from Diaphus watasei, after salting (Boopendranath et al., 2012).

Shaviklo, \& Rafipour, (2011) developed a fish snack from Benthosema pterotum using flavoring, smoking, and drying processes. The product was crispy, slightly salty and smoky, and was accepted by Thai consumers. This product could be marketed in other Asian markets by further optimizing production conditions and improving sensory quality (Shaviklo, 2017).

\section{Fish Seasoning}

Seasoned products from Stenobrachius nannochir and Benthosema pterotum were developed by Noguchi, (2004) and Shaviklo, \& Rafipour, (2011) respectively. Seasoned Benthosema pterotum was made using various spices during the processes of flavoring, smoking, and drying. It had no fishy odor and tasted like trout smoked fillet in terms of sensory characteristics. It was noted that the product could be placed on the market along with noodles or put into a suitable packaging as a seasoning (Shaviklo, 2017).

\section{Fish Proteins Products}

Different methods, including leaching, solubilization/precipitation, enzymatic/acidic hydrolyzation, and solvent extraction with isopropyl alcohol were used for extracting proteins from myctophids by several researchers. (Noguchi, 2004) reported the development of surimi from lanternfishes. 
In another study, leaching was used to extract myofibrillar proteins from lanternfish Benthosema pterotum. Shaviklo, \& Rafipour, (2013) reported significant differences between myctophids mince and surimi for protein, moisture, fat and ash contents, and $\mathrm{pH}$. Moisture gain and removal of some soluble proteins and fat occurred during the leaching process (Shaviklo, et al., 2010a). Myctophids mince contained 16.9\% protein, $77.5 \%$ moisture, $2.3 \%$ fat and $3.2 \%$ ash. These parameters for raw surimi were $14.1,84.8,0.3$, and $0.7 \%$, respectively (Shaviklo, \& Rafipour, 2013). The TVBN of the mince was 30.1 (mgN/ $100 \mathrm{~g}-1)$; it was reduced to 6.6 (mgN/ $100 \mathrm{~g}-1$ ) after converting it to the surimi due to the elimination of nitrogen compounds and sarcoplasmic proteins during the leaching of the mince. The peroxide value $(\mathrm{meq} / \mathrm{kg}$ ) and TBARS $(\mathrm{mg}$ malondialdehyde/ $\mathrm{kg}$ ) of the mince were 5.3 and 2.4 , but it decreased to 0.9 and 0.1 , respectively, because of the elimination of high-fat level and lipid oxidation products during the washing of the mince (Shaviklo, Thorkelsson, Arason, Kristinsson, \& Sveinsdottir, 2010a). The samples had a bright gray color and no odor or taste of the fish. In addition, samples were lacking pathogenic microorganisms and its microbial quality was within the standard (Shaviklo, \& Rafipour, 2013). The gel-forming ability of myofibrillar proteins extracted from lanternfish was higher than that observed for myofibrillar protein extracted from the silver carp and Kilka fishes (Shaviklo, 2017). A 50\% surimi yield from myctophids was obtained which is higher than that reported for other fish species (Shaviklo, \& Rafipour, 2013). The surimi yield in the industrial surimi scale varies between $22-32 \%$, depending on fish species (Lee, 1986). Therefore, the yield of myctophids surimi has an advantage in the surimi industry since product yield is important from an economical point of view. Shaviklo, \& Rafipour, (2013) studied the microbial properties of mince, as well as surimi from whole un-gutted myctophids mince (Table 10). They found that microbial counts have decreased during the washing process. Microbial counts of myctophids surimi were $3 \times 10^{3}$ CFU/g for aerobic plate count, <10 MPN/g for total Coliforms, $<100 \mathrm{CFU} / \mathrm{g}$ for Staphylococcus aureus and $<10 \mathrm{CFU} / \mathrm{g}$ for yeasts and molds. The absence of Salmonella and E. colispp. and low counts of Coliforms and Staphylococcus aureus approved the safety of the surimi for human consumption from a hygienic point of view (Table 10). The primary aerobic plate count of myctophids mince was $7.1 \times 10^{5} \mathrm{CFU} / \mathrm{g}$ that was higher than values reported for other fish species due to contamination of fish flesh by the viscera during mincing. Nevertheless, the microbial quality of the myctophids mince was within the health standard criteria, a critical issue for developing surimi from whole ungutted myctophids mince. The microbial load decreased during leaching to $3.1 \times 10^{3} \mathrm{CFU} / \mathrm{g}$ which was lower than that reported for top-grade surimi (Alaska Pollock, $5.5 \times 10^{4} \mathrm{CFU} / \mathrm{g}$ ) (Himelbloom, Brown, \& Lee, 1991), Atlantic Pollock surimi $\left(3.1 \times 10^{4} \mathrm{CFU} / \mathrm{g}\right)$ (Ingham, \& Potter, 1987) and surimi made from Pollock processing by-product $\left(1.9 \times 10^{5} \mathrm{CFU} / \mathrm{g}\right)$ (Himelbloom, Brown, \& Lee, 1989). The absence of pathogens indicated that the myctophids surimi was microbiologically safe and suitable for human consumption.

A solubilization/precipitation method was used to extract protein from Benthosema pterotum and its functional properties were investigated. For this purpose, low $\mathrm{pH}(2.5,3.0,3.5)$ and high $\mathrm{pH}(10.5,11.0$, 11.5) were used to extract proteins from myctophids. The effects of these treatments on protein yield, oxidation, and functional properties of the proteins were investigated. According to the results, alkaline treatment with $\mathrm{pH} 11.5$ was identified as the optimum treatment in the production of myctophids protein isolates. According to the results, it was found that the myctophids protein isolate had good functional properties even during frozen storage (Shaviklo, 2017).

$$
\text { Oliyaei, Moosavi-Nasab, Ghorbani, }
$$

Sadeghimahoonak, \& Maghsoudloo, (2015) investigated the chemical analysis and functional characteristics of the Benthosema pterotum protein isolates. They found that alkaline treatments had a significant effect on fat reduction and, with increasing $\mathrm{pH}$, the fat content significantly decreased. In addition, the functional properties improved with increasing $\mathrm{pH}$. In addition, they pointed out that the protein isolate derived from the lanternfish has good functionality and that alkaline treatments improved the protein efficiency and color properties (Oliyaei et al., 2015).

In another study, extraction of the Benthosema pterotum protein was carried out in alkaline $\mathrm{pH}$ (10 and 12) followed by precipitation at its isoelectric $\mathrm{pH}$. The influence of different extraction temperatures $(0,4,11$,

Table 10. Microbiological analysis of myctophid mince and surimi

\begin{tabular}{|c|c|c|c|}
\hline Analysis & Mince & Surimi & Surimi seadood \\
\hline Total aerobic bacteria counts (CFU/g) & $7.1 \times 10^{5}$ a & $3 \times 10^{3 c}$ & $5 \times 10^{4 b}$ \\
\hline Coliforms at $45^{\circ} \mathrm{C}$ (MPN/g) & $9.1 \times 10^{1}$ a & $0.9 \times 10^{1 b}$ & $8.8 \times 10^{1}$ a \\
\hline Salmonella (in 25g) & absence & absence & absence \\
\hline Staphylococcus aureus (CFU/g) & $9.3 \times 10^{2}$ a & $7.5 \times 10^{1 c}$ & $5 \times 10^{2 b}$ \\
\hline E.coli (MPN/g) & $0.9 \times 10^{1}$ a & $0^{\mathrm{b}}$ & $0^{b}$ \\
\hline Yeasts and molds (CFU/g) & $9.5 \times 10^{1}$ a & $0.6 \times 10^{1 b}$ & $0.8 \times 10^{1 b}$ \\
\hline
\end{tabular}

Adapted from Shaviklo, \& Rafipour, (2013). MPN: most probable number; CFU: colony forming unit. Different superscripts show significant differences within a row $(p<0.05)$ 
25 , and $30^{\circ} \mathrm{C}$ ) was also investigated. The results indicated that the protein recovery yield at $\mathrm{pH} 12$ was greater than that found when extracting at $\mathrm{pH} 10$. Furthermore, water holding capacity, oil-holding capacity, foaming capacity, emulsifying capacity, and solubility of the proteins isolated at $\mathrm{pH} 12$ were greater than at $\mathrm{pH} 10$. The color evaluation $\left(L^{*}, a^{*}\right.$, and $\left.b^{*}\right)$ of the samples showed protein isolated at $\mathrm{pH} 12$ was lighter (higher $L^{*}$ ) than protein isolated at $\mathrm{pH} 10$, but redness ( $a^{*}$ value) reduced in both samples. Extraction at different temperatures revealed that protein recovery yield and functional properties were improved by increasing temperature (Oliyaei, Ghorbani, MoosaviNasab, Sadeghimahoonak, \& Maghsoudloo, 2017).

Nair et al., (1983) produced hydrolyzed protein from Benthosema pterotum with a yield of $5 \%$ wet weight and 10 months shelf life. Boopendranath et al., (2012) found that the yield of fish protein hydrolysate (FPH) developed from Diaphus watasei, using pepsin, bromelain, and papain was 2.0, 4.5 and $6.5 \%$, respectively. FPH from Diaphus watasei contained 79.0 90.6\% protein, $0.7-1.2 \%$ fat, $5.8-7.7 \%$ moisture and 2.8 $11.2 \%$ ash content. The FPH prepared from myctophids has shown many desirable properties for its use in the food/feed industry as reported by Boopendranath et al., (2012).

Chai et al., (2012) developed protein myctophids hydrolysates (Benthosema pterotum) (MPH's) rich in proteins, and nutrients such as amino acids, phospholipids, and antioxidant compounds. The products were free of wax esters and declared safe for human and animal consumption. Chai, Yi-Lin, Tsung-Lin, Chyuan-Yuan, \& Chang-Jer, (2013) developed fish protein hydrolysate from fresh whole Benthosema pterotum using Protease A and N, Prozyme 6 or Protamex. Strong antioxidant activities were observed in the Protease- $\mathrm{N}$ treated myctophid protein hydrolysate and the sequences of oligopeptides with the greatest antioxidant functionality were identified to be Phe-Tyr-Tyr and Asp-Trp. The capability of MPHs to prohibit $\mathrm{H}_{2} \mathrm{O}_{2}$-induced DNA loss was approved in an $\mathrm{H}_{2} \mathrm{O}_{2}$ toxicity test. The authors concluded that MPH has high-grade antioxidants and may prohibit neurodegenerative illnesses. MPH might be used as a valuable ingredient for anti-aging functional food product development. Chai, Wu, Yang, Li, \& Pan (2016) reported $13.2 \mathrm{mg} / \mathrm{g}$ of active peptides for $\mathrm{MPH}$ from Benthosema pterotum. They concluded that the $\mathrm{MPH}$ might be considered as a novel nutraceutical for easing and/or healing of age-related neurodegenerative disorders.

Fallah, Aftabsavar, Bahri, Ghodrati Shojaei, \& Karimzadeh, (2011) developed fish protein concentrate (FPC) from Benthosema pterotum using a solvent extraction method with isopropyl alcohol. Proximate analysis, microbial quality and nutritional values of the products were examined. The FPC contained $74.5 \%$ protein, $0.6 \%$ fat, $4.7 \%$ moisture and $0.9 \%$ ash. The product was pathogen-free, with light gray color and mild odor and flavor. The authors concluded that FPC made from this myctophids could be used as an ingredient in the food industry.

Shaviklo, (2012b) reported the production of protein powder from Benthosema pterotum for human consumption using spray drying and freeze-drying process with a shelf life of more than 6 months. The protein and moisture of the freeze-dried and spray dried myctophids protein powder (MPP) were 65.2 and $67.0 \%$ and 4.8 and $3.5 \%$ respectively. The results indicated that the freeze-drying method is superior to the spray dryer. In addition, dried myofibrillar proteins had better functional properties and a lighter color than myctophids protein isolate powder. The MPP had no taste and smell of fish, an indication of top quality products. This product can be vacuum-packed and stored for 6 months at ambient temperature. If the product is stored at refrigerated temperatures, the shelf life extends to more than one year. The MPP can be applied as an ingredient in the manufacture of various and ready-to-eat foods, as well as enrichment of various food products, including cereal snacks. It can also be a protein source to overcome malnutrition in poor countries (Shaviklo, 2012b; Shaviklo, 2017).

\section{Fermented Products}

Teutscher, (2001) and Shaviklo, (2017), developed fermented products such as fish sauce and silage. Fish sauce from Benthosema pterotum was compared to the local fish sauce products. Fish silage is a hydrolyzed protein solution developed from whole fish or fish byproducts using enzymes, acids or both. Fish silage produced from Diaphus watasei was recommended as an alternative to fishmeal (Boopendranath et al., 2012).

\section{Formulated Seafood Products}

Lanternfishe protein derivatives, including mince, surimi, protein isolate, hydrolysate, and powder, can be used in the food industry due to their functional properties and stability (Shaviklo, 2012) and several studies investigated this potential. Shaviklo and Rafipour, (2013) introduced 70\% myctophids surimi into the fish burger formula and examined the product's quality after the breading and frying processes. The breaded and deep-fried burger of this species contained 1.1 (meq/kg) peroxide and 0.2 (mg malondialdehyde/ $\mathrm{kg}$ ) TBARS and 7.2 (mgN/ $100 \mathrm{~g}-1)$ TVBN values. The product had gray color, but its sensory characteristics (texture and flavor) were better than the fish burger made from silver carp, Kilka fish, and threadfin bream. Microbiological tests indicated that the products were pathogen free and safe for human consumption (Table 10).

Boopendranath et al., (2012), developed a ready to cook and coated product from Diaphus watasei mince. They stated that the taste of fresh, whole fish was not accepted, but when treated with condiments as in the 
case of marinated products, its acceptability score increased considerably. They also studied the shelf stability of the frozen product at a storage temperature of $-20^{\circ} \mathrm{C}$, for one year. The sensory scores have shown that the acceptability of the myctophids product has been less when compared with the anchovy-based control product.

Das et al., (2015) prepared a ready-to-eat coated product from the myctophids Diaphus Watasei and studies microbial changes during frozen storage (Table 11). To develop the products myctophids were beheaded, and de-gutted with skin on and then washed with chilled water, followed by marinating in salt and lemon juice; the marinated fishes were battered and coated with breadcrumbs. The products were then packed in small Styrofoam trays with the top being covered with transparent polyethylene film, frozen at $-40^{\circ} \mathrm{C}$ for $4 \mathrm{~h}$ and stored at $-20^{\circ} \mathrm{C}$ for one year. The myctophids samples had an aerobic plate count ranging from $1.5 \times 10^{6}$ to $2.4 \times 10^{6} \mathrm{CFU} / \mathrm{g}$, while the total Enterobacteriaceae count ranged from $8.9 \times 10^{2}$ to $7.4 \times 10^{4} \mathrm{CFU} / \mathrm{g}$. One sample (Myctophum obtusirostre) was found positive for coagulase staphylococci and the presence of coliform was detected in another sample (Myctophum spinosum). Fecal streptococci were not detected in any of the three species' samples. For the coated product prepared from Diaphus watasei, the aerobic plate count at $37^{\circ} \mathrm{C}$ showed an increase from 0 days to 2 months $\left(1.7 \times 10^{4}\right.$ to $\left.6.6 \times 10^{4} \mathrm{CFU} / \mathrm{g}\right)$ and decrease thereafter during frozen storage up to 12 months $\left(6.4 \times 10^{3} \quad \mathrm{CFU} / \mathrm{g}\right)$. The total Enterobacteriaceae and fecal streptococci population decreased during frozen storage to $<100 \mathrm{CFU} / \mathrm{g}$ after 12 months of storage from their initial count (after freezing) of $5.6 \times 10^{2}$ and $3.4 \times 10^{2} \mathrm{CFU} / \mathrm{g}$, respectively. The initial count of total psychrophilic bacteria in the product prepared from Diaphus watasei was more than that of total aerobic bacteria (mesophilic). However, at the end of storage, no significant difference was observed in both these counts (Table 11).

The use of lanternfishe protein isolates in the formulation of meat sausage was also investigated. Based on this experiment, adding $2 \%$ of the lanternfishe protein isolate to veal sausages formula improved the texture and taste of the product. It was also possible to cold- store this product for a period of 60 days (MoosaviNassab, Mohammadi, \& Oliyaei, 2018).

\section{Industrial Use}

In addition to the possibility of direct consumption of mesopelagic species, including myctophids, there is interest in using them for industrial applications like a lubricant (Noguchi, 2004). Wax ester oil has high stability at elevated temperatures in contrast to the more common triacylglycerol rich fish oils. Marine wax ester oils have also been used in cosmetics as a substitute for jojoba oil, itself a replacement for sperm whale oil sold in Japan. Wax esters are used as lubricants in the steel industry and have been incorporated into a variety of degreasing and cleaning products (Nichols, Nichols, \& Volkman, 1993). Noguchi (2004) reported that the quality of myctophids wax was as good as the wax of the orange roughy (Hoplostethus atlanticus), a larger deep-sea fish used as a raw material for cosmetics and other industrial applications. Accordingly, the lanternfish species Electrona Antarctica could be used for such products (Phleger et al., 1991). Primary research has also indicated the anti-inflammatory and analgesic properties of myctophids oil and its potential to relieve age-associated disorders (Boopendranath et al., 2012). Further studies should be carried out in this regard.

\section{Challenges for the Utilization of Myctophids Fishes}

The above review underscores the potential of myctophids species for human consumption and industrial applications. To that end, it is important to accurately estimate myctophids biomass, to understand their relationship to other members of the food web, and their interaction with oceanic habitats and biological and chemical oceanographic processes and cycles (Irigoien, Klevjer, Røstad, Martinez, Boyra, Acuña, et al., 2014; St. John, et al., 2016; Hidalgo, \& Browman, 2019). The data obtained from investigations are necessary to ensure the sustainable management of these short-lived mesopelagic species (Hidalgo, \& Browman, 2019).

For long-term stable utilization, it is necessary to have a continuous, sustainable supply of myctophids. Myctophids have very fragile skin which is very susceptible to damage and spoilage during handling. Long fishing times and rough handling accelerate the autolysis processes and shorten shelf life even at

Table 11. Microbiological quality of coated product of $D$. watasei during frozen storage (CFU/g)

\begin{tabular}{lcccc}
\hline Microbiological parameters & \multicolumn{3}{c}{ Storage times (months) } \\
\cline { 2 - 4 } & 0 & 4 & 8 & 12 \\
\hline Aerobic plate count & $1.7 \times 10^{4}$ & $6.6 \times 10^{4}$ & $1.0 \times 10^{4}$ & $6.4 \times 10^{3}$ \\
Total Enterobacteriaceae & $5.6 \times 10^{2}$ & $3.0 \times 10^{2}$ & $<100$ & $<100$ \\
Total coliforms & $<100$ & 0 & 0 & 0 \\
Coagulase positive staphylococci & 0 & 0 & 0 & 0 \\
Fecal streptococci & $3.4 \times 10^{3}$ & $1.1 \times 10^{2}$ & $<100$ & $<100$ \\
Psychrophilic bacteria & $3.0 \times 10^{5}$ & $3.7 \times 10^{4}$ & $8.8 \times 10^{3}$ & $7.2 \times 10^{3}$ \\
\hline
\end{tabular}

Adapted from: Das et al., (2015), CFU: Colony forming unit 
refrigeration temperatures. The limited shelf life is a large hurdle for the utilization of lanternfishes (Shaviklo, 2012). It should be noted that to obtain high valueadded products, such as, omega-3, the raw material must be fresh (Prellezo, 2019). Quick handling and onboard freezing are recommended if onshore facilities are going to be used for myctophids processing (Aftabsavar, 1992; Shaviklo, 1994; Moradi, 2001).

The seasonality of myctophids fishing is another factor that needs to be considered (Valinassab et al., 2007) and it couldn't be an issue when planning largescale production of proteins and peptides. Although the qualities of lipids and protein of myctophids fishes have been shown not to differ much from those of commercial fishes, the non-migratory species have wax esters and are, therefore, not suitable for human consumption (Catul et al., 2011). There is also a need to produce proteins and peptides with documentation of health evidence. There are also other, bigger challenges concerning clinical testing, documentation, standardization, and quality.

Color of myctophids flesh is a challenge for making food products. The dark color of myctophids surimi and even darker color of myctophids mince make it difficult to develop acceptable ready-to-eat products (Shaviklo, \& Rafipour, 2013). Studies of possible ways to lighten the surimi dark color are therefore needed. More research is also required for myctophids characterization and utilization. Marketing new products is very difficult when the expectations of consumers are unknown (Shaviklo, 2016). There is also a need to conduct market research on the use of myctophids products for human consumption. However, these shortcomings are not insurmountable and will be resolved once catching of myctophids becomes economically viable.

\section{Concluding Remarks}

This paper reviewed the physicochemical characterization and product development of myctophids, a group comprising large biomass of mesopelagic fishes. The study documents the challenges for the utilization of this fish species. Of specific importance, the paper also discusses the practical application of myctophids fishes in food and feed systems. Based on extensive studies on the characterization and application of lanternfish for animal and human consumption, it is evident that these fish have nutritional value and chemical composition similar to that of other aquatic animals and can be used to produce a variety of products for human consumption and animal feed/ industrial use. Many species of myctophids are rich in wax esters, but the edible species, like Benthosema pterotum, are lacking in this substance and can be applied for the production of high value-added products without any concerns. The results of the initial prototyping of value-added products revealed the optimal use of these marine fishes for human consumption. Developing the myctophids industry depends on converting such raw material to value-added products for human consumption and industrial uses. To ensure utilization of myctophids for human consumption, it is necessary to (1) provide a high quality of catch; (2) develop processing methods for adding value to the myctophids; (3) conduct consumer surveys on myctophids based products; (4) provide documentation of properties, including bioactive properties; and (5) standardize the process and properties of the myctophids. Evidently, myctophids could prove to be a promising source of fish protein and oil for the coming decades.

\section{Acknowledgments}

I wish to acknowledge the support provided by the Animal Science Research Institute of Iran and Guilan Science and Technology Park (GSTP), Rasht, Iran. My special thanks are extended to Mr. Ofer Gon of the South African Institute for Aquatic Biodiversity for editing the manuscript.

\section{References}

Ababouch, L. (2012). Fish utilization and trade. In J. Ryder, L. Ababouch, \& M. Balaban, (Eds.), Second International Congress on Seafood Technology on Sustainable, Innovative and Healthy Seafood, Food And Agriculture Organization of The United Nations Rome, p 9-31

Aftabsavar, Y. (1992). Changes in the quality of lanternfish (Benthosema pterotum) during transportation at ambient temperatures. Iranian Scientific Fisheries Journal, 6, 1-12 [in Persian]

Ariyawansa, S. (2000). The evaluation of functional properties of fishmeal. United Nations University-Fisheries Training Programme, Final report, Reykjavík, Iceland. Available from

http://www.unuftp.is/static/fellows/document/sujeew a3.pdf

Aygul, K., \& Mehmet, C. (2008). Amino acid composition of blue crab (Callinectes sapidus) from the northeastern Mediterranean Sea. Journal of Applied Biological Sciences, 1, 39-42

Azimi, A., Hosseini, S., Sudagar, M., \& Aslanparviz, H. (2011). Effect of replacement of Caspian Sea gammarus meal by partial kilka fishmeal on growth performance, feed conversion ratio and survival of juveniles of rainbow trout (Oncorhynchus mykiss). Iranian Scientific Fisheries Journal, 3, 63-74 [in Persian]

Baby, L., Sankar, T.V. \& Anandan, R. (2014). Comparison of lipid profile in three species of myctophids from the southwest coast of Kerala, India. National Academy Science Letters, 37, 33-37. https://doi.org/10.1007/s40009-013-0185-4

Bahri, A., Afkhami, M., Ehsanpour, M., \& Mokhlesi, A. (2015). Myctophids: Great Fatty Acids Resources from Gulf of Oman. Journal of Oceanography, 3, 11-17 [in Persian]

Balu, S., \& Menon, N.G. (2006). Lantern fish: a potential deepsea resource. ENVIS Marine Marine Offshore Ecosyst 5(1). Available:

http://www.dgukenvis.nic.in/newsletters/News letter14.pdf. 
Boopendranath, M.R., Vijayan, P.K., Remesan, M.P., Anandan, R., Ninan, G., Zynudheen, A. A., Das, S., Rajeswari, G., Raghu Prakash, R., Sankar, T.V., Panda, S.K., Mohan, C.O., Vipin, P.M., Jose Fernandez, T., Ravi, R., Mahato, P.K., Pradeep, K., Rajamoorthy, K., Muhammed Sherief, P.S., Baby, L., \& Abhilash, S. (2012). Development of Harvest and Post-harvest Technologies for Utilization of Myctophid Resources in the Arabian Sea, Final Report on CIFT Project Component, Central Institute of Fisheries Technology (Indian Council of Agricultural Research) Matsyapuri, Cochin, India

Catul, V., Gauns, M., \& Karuppasamy, P.K. (2011). A review on mesopelagic fishes belonging to family Myctophidae. Reviews in Fish Biology and Fisheries, 21, 339-354. https://doi.org/10.1007/s11160-010-9176-4

Chai, H., Chan, Y. Li, T., Chen, Y., Wu, C., \& Shiau, C.W.C. (2012). Composition characterization of myctophids (Benthosema pterotum): Antioxidation and safety evaluations for myctophids protein hydrolysates. Food Research International, 46, 118-126. https://doi.org/10.1016/j.foodres.2011.12.008

Chai, H.J, Yi-Lin, C., Tsung-Lin, L., Chyuan-Yuan, S., \& Chang-Jer, W. (2013). Evaluation of lanternfish (Benthosema pterotum) hydrolysates as antioxidants against hydrogen peroxide induced oxidative injury. Food Research International, 2, 1409-1418 https://doi.org/10.1021/jf020578n

Chai, H-J, Wu, C-J., Yang, S-H., Li, T-L., \& Pan, B.S. (2016). Peptides from hydrolysate of lanternfish (Benthosema pterotum) proved neuroprotective in vitro and in vivo. Journal of Functional Food, 24, 438-449 https://doi.org/10.1016/j.jff.2016.04.009

Das, S., Jose Fernandez, T.J., \& Lalitha, K.V. (2015). Microbiological quality of myctophid fish of the Arabian Sea. Fishery Technology, 52, $194-197$

El-Mowafi, A., Nanton, D., \& Berntssen, M. (2010). Evaluation of lanternfish (Benthosema Pterotum) as marine source in fish feeds: nutrient composition and contaminants assessment. Proceeding of the 3rd Global Fisheries \& Aquaculture Research Conference. Foreign Agricultural Relations (FAR), Egypt, 29th Nov.-1st Dec., (2010) pp. 12 $-23$

Fallah, F., Aftabsavar, Y., Bahri, A., Ghodrati Shojaei, M., \& Karimzadeh, R. (2011). Developing fish protein concentrate (FPC) from myctophid (Benthosema Pterotum) using solvent extraction method. National Food Congress, Islamic Azad University, Ghochan, Iran [in Persian]

FAO. (1986). The production of fish meal and oil. Food and Agriculture organization of the United Nations. Rome, Italy

FAO. (1997). fisheries Lanternfishes: a potential fishery in the northern Arabian Sea. Available: http://www.fao.org/ docrep/003/w4248e/w4248e34.htm

FAO. (2001). Report of the trilateral workshop on lanternfish in the Gulf of Oman. Food and Agriculture Organization Available:

ftp://ftp.fao.org/docrep/fao/007/y2967e/y2967e00.pdf

FAO. (2020). The State of World Fisheries and Aquaculture 2020. Sustainability in action. Rome. https://doi.org/10.4060/ca9229en

FAO/WHO. (1991). Energy and protein requirements. Report of a Joint FAO/WHO/UNU Expert Consultation. World Health Organization Technical Report Series 724, Switzerland
Gjøsæter, J., \& Kawaguchi, K. (1980). A review of the world resources of mesopelagic fish, FAO Fisheries Technical Papers, 193, FAO, Rome

Gjøsæter, J. (1984). Mesopelagic fish, a large potential resource in the Arabian Sea. Deep-Sea Research, 31, 1019-1035

Gopakumar, K., Nair, K.G. R., Nair, P.G. V., Nair, A.L., Radhakrishnan, A.G., \& Nair, P.R. (1983). Studies on lanternfish Benthosema pterotum biochemical and microbiological investigations. Fishery Technology, 20, 17-19

Gopakumar, K. (1997). Amino acid composition of muscle proteins of Indian food fish and shellfish, In: Biochemical Composition of Indian Food Fishes (Gopakumar K, Ed.). $2^{\text {nd }}$ edn. Central Institute of Fisheries Technology, Cochin, India, p. 9-17

Haque, A., Peterson, H.A., Larsen, J.T., \& Opstvedt, J. (1981). Fish meal and oil from lanternfish (Myctophidae) with special emphasis on protein quality. Journal of Science of Food \& Agriculture, 32, 61-70 https://doi.org/10.1002/jsfa.2740320110

Hidalgo, M., \& Browman, H.I. (2019). Developing the knowledge base needed to sustainably manage mesopelagic resources. ICES Journal of Marine Science, 76(3), 609-615 https://doi.org/ 10.1093/icesjms/fsz067

Himelbloom, B.H., Brown, E.K., \& Lee, J.S. (1989). Microbiological profiling of surimi productions, Alaska Fisheries Development Foundation, Final Report, Anchorage, AK

Himelbloom, B.H., Brown, E.K., \& Lee, J.S. (1991). Microbiological evaluation of Alaska shore-based surimi. Journal of Food Science, 56, 291-293 https://doi.org/10.1111/j.1365-2621.1991.tb05264.x

Hulley, P.A. Lanternfishes. (1996). In J.R. Paxton, \& W.N. Eschmeyer (Eds.), Encyclopedia of fishes, Academic Press, London, 127-128

Ingham, S.C., and Potter, N.N. (1987). Microbial growth in surimi and mince made from Atlantic pollock. Journal of Food Protectection, 50, 312-315 https://doi.org/10.4315/0362-028X-50.4.312

Irigoien, X., Klevjer, T. A., Røstad, A., Martinez, U., Boyra, G., Acuña, J. L., Bode, A., Echevarria, F., Gonzalez-Gordillo, J. I., Hernandez-Leon, S., Agusti, S., Aksnes, D. L., Duarte, C.M., \& Kaartvedt, S. (2014). Large mesopelagic fishes biomass and trophic efficiency in the open ocean. Nature Community, 5, 3271-3280 https://doi.org/ 10.1038/ncomms4271

Jose Fernandez, T., Pradeep, K., Anandan, R., Zynudheen, A.A., \& Sankar, T.V. (2014). Comparison of nutritional characteristics of myctophid fishes (Diaphus effulgens and $D$. hudsoni) with common Indian food fishes. Fishery Technology, 3, 173-178

Kiaei, M., Sanei, M., \& Farkhori, M. (2001). An investigation on nutritional value of myctophid meal from Oman sea comparing to imported fish meal from Peru. Chakavak Scientific Journal, 10: 118-129 [in Persian]

Kim, S. (2014). Seafood Processing By-Products Trends and Applications, $1^{\text {st }}$ Edition, Springer-Verlag New York

Koizumi, K., Hiratsuka, S., \& H. Saito. (2014). Lipid and fatty acids of three edible myctophids, Diaphus watasei, Diaphus suborbitalis, and Benthosema pterotum: high levels of icosapentaenoic and docosahexaenoic acids. Journal of Oleo Science, 63, 461-470 https://doi.org/ 10.5650/jos.ess13224 
Kozlov, A.N. (1995). A review of the trophic role of mesopelagic fish of the family Myctophidae in the Southern Ocean ecosystem. CCAMLR Sci 2:71-77. Available: http:// ir.library.oregonstate.edu/dspace/bitstream/1957/872 6/1/COAS_ref_67_14.pdf

Lea, M.A., Nichols, P.D., \& Wilson, G. (2002). Fatty acid composition of lipid-rich myctophids and mackerel ice fish (Champsocephalus gunnari) Southern Ocean foodweb implications. Polar Biology, 25, 843-854 https://doi.org/10.1007/s00300-002-0428-1

Lee, C.M. (1986). Surimi manufacturing and fabrication of surimi-based products. Food Technology, 3, 115-124

Lekshmy, N.A., Arul, J. M., Mathew, P.T., \& Gopakumar, K. (1983). Studies on lanternfish (Benthosema pterotum) II. Nutritional Evaluation. Fishery Technology, 20, 17-19

Madhupratap, M., Nair, K.N.V., Gopalakrishnan, T.C., Haridas, P., Nair, K.K.C., Venugopal, P., \& M. Gauns. (2001). Arabian Sea oceanography and fisheries of the west coast of India. Current Science, 81(4):355-361

Mahato P.K., Baby, L., Sankar, T.V., Anandan, R., Vijayan, P.K., Ninan, G., \& Zynudheen, A.A. (2009). Myctophids: An Alternate Protein Source from Deep Sea. In Coastal Fishery Resources of India: Conservation and Sustainable Utilisation. Proceedings of the National Seminar on Conservation and Sustainability of Coastal Living Resources of India, 1-3 December, Cochin

Moosavi-Nasab, M., Mohammadi, R., \& Oliyaei, N. (2018). Physicochemical evaluation of sausages prepared by lanternfish (Benthosema pterotum) protein isolate. Food Science \& Nutrition, 6, 617-626 https://doi.org/ 10.1002/fsn3.583

Mori, M., Saito, T., Nakanishi, Y., Miyazawa, K., \& Hashimoto, Y. (1996). The composition and toxicity of wax in the flesh of castor oil fishes. Bulletin of the Japanese Society of Scientific Fisheries, 32, 137-145 https://doi.org/10.2331/suisan.32.137

Moradi, G. (2001). Handling and processing of lanternfish, report of the trilateral workshop on lanternfish in the Gulf of Oman, FAO Fisheries Report No: 665, FAO, Rome: 8

Moser, H.G. and W. Watson. (2006). Myctophiformes. In W.J., Richards, (Ed.), Early stages of Atlantic fishes - An identification guide for the Western Central North Atlantic. 1st Edn., Net Library Inc., Boulder, Colorado Moser, 461-580

Nafpaktitis, B.G. (1982). Myctophidae. In W., Fischer, \& G. Bianchi, (Eds.), FAO species identification sheets for fishery purposes (3rd Edn.), FAO publication, Western Indian Ocean, 1-8 Available at: http://www.fao.org/3/ad468e/AD468elO.pdf

Nair, L.A., Arul, J.M., Mathew, P.T., \& Gopakumar, K. (1983). Studies on lanternfish (Benthosema pterotum) II. Nutritional evaluation. Fishery Science, 1, 20-23

Navaneethan, R., Anandan, R., Jose Fernandez, T., Pradeep, K., Mathew, S., \& Sankar, T.V. (2014). Comparative analysis of fatty acid profile of fish oils extracted from Diaphus watasei and sardinella longiceps. Fishery Technology, 3, $225-227$

Nichols, P.D., Nichols, D.S., \& Volkman, J.K. (1993). Recent developments with marine oil products in Australia. Chemistry Australia, 7, 336-340

Neighbors, M.A., \& Nafpaktitis, B.G. (1982). Lipid compositions, water contents, swim bladder morphologies and buoyancies of nineteen species of midwater fishes (18 Myctophids and 1 Neoscopelid). Marine Biology, 66, 207-215

https://doi.org/10.1007/BF00397024

Neiohbors, M.A. (1988). Triacylglycerols and wax esters in the lipids of deep midwater teleost fishes of the Southern California Bight. Marine Biology, 98, 15-22. https://doi.org/10.1007/BF00392654

Nevenzel, J.C., Rodegker, W., Stephen, J., \& Kayama, M. (1969). The lipids of some lanternfishes (Family: Myctophidae). Comparative Biochemistry and Physiology, 31, 25-36

https://doi.org/10.1016/0010-406X(69)92165-3

Noguchi, S.F. (2004). Utilisation of the resources of lanternfish as fisheries products, In M., Sakaguchi, (Ed.), More Efficient Utilization of Fish and Fishery Products, Elsevier, Amsterdam, Netherlands, 63-66

Oliyaei, N., Moosavi-Nasab, M., Ghorbani, M., Sadeghimahoonak, A.R., \& Maghsoudloo, Y. (2015). Evaluation of composition and functional properties of protein isolated from Myctophid (Benthosema pterotum) by using $\mathrm{pH}$ shift method. Iranian Scientific Fisheries Journal, 1, 25-35 [in Persian]

Oliyaei, N., Ghorbani, M., Moosavi-Nasab, M., Sadeghimahoonak, A.R., \& Maghsoudloo, Y. (2017). Effect of temperature and alkaline ph on the physicochemical properties of the protein isolates extracted from the whole ungutted lanternfish (Benthosema pterotum). Journal of Aquatic Food Products Technology, 26,10, 1134-1143 https://doi.org/10.1080/10498850.2014.940564

Olivar, M. P., Bode, A., Lo'pez-Pe'rez, C.P., Hulley, A., \& Herna'ndez-Leo'n, S. (2019). Trophic position of lanternfishes (Pisces: Myctophidae) of the tropical and equatorial Atlantic estimated using stable isotopes. ICES Journal of Marine Science, 76(3), 649-661 https://doi.org/10.1093/icesjms/fsx243

Oxley, A., Bogevik, A.S., Henderson, A.S., Waagbo, R.J., Tocher, R., \& Olsen, R.E. (2009). Digestibility of Calanus finmarchicus wax esters in Atlantic salmon (Salmo salar) freshwater presmolts and seawater postsmolts maintained at constant water temperature. Aquatic Nutrition, 15, 459-469 https://doi.org/10.1111/j.1365-2095.2008.00611.x

Pakhomov, E.A., Perissinotto, R., \& McQuaid, C.D. (1996). Prey composition and daily rations of myctophid fishes in the Southern Ocean. Marine Ecology Progress Series, 134,114

Phleger, CF., Nichols, P.D., \& Virtue, P. (1991). The lipid, fatty acid and fatty alcohol composition of the myctophid fish Electrona antarctica: high level of wax esters and foodchain implications. Antarctic Science, 3, 258-265 https://doi.org/10.1017/S0954102097000345

Phleger, C.F., Nelson, M.M., Mooney, B.D., \& Nichols, P.D. (1999). Wax esters versus triacylglycerols in myctophid fishes from the Southern Ocean. Antarctic Science, 4, 436-444 https://doi.org/10.1017/\$0954102099000565

Prellezo, R. (2019). Exploring the economic viability of a mesopelagic fishery in the Bay of Biscay. ICES Journal of Marine Science, 76(3), 771-779 https://doi.org/10.1093/icesjms/fsy001

Rajamoorthy, K., Pradeep, K., Anandan, R., Baby, L., Sankar, T. V., \& Lakshmanan, P.T. (2013). Biochemical Composition of Myctophid Species Diaphus watasei and Myctophum 
obtusirostre Caught from Arabian Sea. Fishery Technology, 50, $41-44$

Reinhardst, B., \& Vanvleet, E.S. (1986). Lipid composition of twenty- two species of Antarctic midwater zooplankton and fish. Marine Biology, 91, 149-159 https://doi.org/10.1007/BF00569431

Saito, H., \& Murata, M. (1996). The high monoene fatty acids in the lipids of some midwater fishes: family Myctophidae, Lipids, 31, 757-763 https://doi.org/10.1007/BF02522892

Saito, H., \& Murata, M. (1998). Origin of the monoene fats in the lipid of midwater fishes: relationship between the lipids of myctophids and those of their prey. Marine Ecology Progress Series, 168, 21-33 https://doi.org/ 10.3354/meps168021

Salvanes, A.G.V., \& Kristofersen, J.B. (2019). Mesopelagic fish. In J.H., Steele, K.K., Turekian, S.A., Thorpe et al (Eds.), Encyclopedia of Ocean Sciences. New York: Academic Press, 3, 1711-1717

Sassa, C., Kawaguchi, K., Hirota, Y., \& Ishida, M. (2004). Distribution patterns of larval myctophid fish assemblages in the subtropical-tropical waters of the western north Pacific. Fish Oceanography, 13(4):267-28 https://doi.org/10.1111/j.1365-2419.2004.00289.x

Sassa, C., Ohshimo, S., Tanaka, H., \& Tsukamoto, Y. (2014). Reproductive biology of Benthosema pterotum (Teleostei: Myctophidae) in the shelf region of the East China Sea. Journal of the Marine Biological Association of the United Kingdom, 94, 423-433 https://doi.org/10.1017/S0025315413001318

Sassa, C., M. Takahashi, and Y. Tsukamoto. (2015). Distribution, hatch-date, growth, and mortality of larval Benthosema pterotum (Pisces: Myctophidae) in the shelf region of the East China Sea. Journal of the Marine Biological Association of the United Kingdom, 95: 161174

https://doi.org/10.1017/\$0025315414001209

Sassa, C. (2019). Estimation of the spawning biomass of myctophids based on larval production and reproductive parameters: the case study of Benthosema pterotum in the East China Sea. ICES Journal of Marine Science, 76(3), 743-754

https://doi.org/10.1093/icesjms/fsy051

Seo, H.S., Endo, Y., Fujimoto, K., Watanabe, H., \& Kawaguchi, K. (1996). Characterization of lipids in myctophid fish in the sub-arctic and tropical Pacific Ocean. Fishery Science, 3, 447-453

https://doi.org/10.2331/fishsci.62.447

Seo, H.S., Endo, Y., Moku, M., Muramoto, K., Fujimoto, K., \& Kawaguchi, K. (1998). Amino acid composition of proteins in myctophid fishes in the subarctic and tropical Pacific Ocean. Fishery Science, 4, 652-653

https://doi.org/10.2331/fishsci.64.652

Shahidi, F. (2006). Maximising the Value of Marine ByProducts,1st Edition, Woodhead Publishing

Shaviklo, G.R. (1994). Fish meal production in Iran. Iran fisheries organization, technical paper, 15 [in Persian]

Shaviklo, G.R., Thorkelsson, G., Arason, S., Kristinsson, H.G., \& Sveinsdottir, K. (2010a). The influence of additives and drying methods on quality attributes of fish protein powder made from saithe (Pollachius virens). Journal of Scienec of Food and Agriculture, 12, 2133-43 https://doi.org/ 10.1002/jsfa.4062

Shaviklo, G.R., Arason, S., Thorkelsson, G., Sveinsdottir, K., \&
Martinsdottir, M. (2010b). Sensory attributes of haddock balls affected by added fish protein isolate and frozen storage. Journal of Sensory Stududies, 3, 316-331 https://doi.org/ 10.1111/j.1745-459X.2009.00260.x

Shaviklo, A.R., \& Rafipour, F. (2011). Feasibility study on product development of myctophid. Iran Fisheries Research Institute. Technical report. [in Persian]

Shaviklo, A.R., \& Rafipour, F. (2013). Surimi and surimi seafood from whole ungutted myctophid mince. LWT Journal of Food Science \& Technology, 2, 463-468 https://doi.org/ 10.1016/j.lwt.2013.06.019

Shaviklo, A.R. (2012a). Developing value-added products from lanternfish, INFOFISH International, 2, 42-46

Shaviklo, A.R. (2012b). Sensory attributes of wet and dry fish proteins recovered from lanternfishes (Myctophids), the European Conference on Sensory and Consumer Research 9-12 September, 2012, Bern, Switzerland

Shaviklo, AR. (2016). Market for value added fishery products in Iran: opportunities, challenges and future perspectives. INFOFISH International, 6, 8-12

Shaviklo, A.R. (2017). Myctophid as human food. World Seafood Congress 10-13 Sep. 2017. Reykjavik, Iceland

Shaviklo, A.R., \& Etemadian, Y. (2019). Overcoming current challenges in commercial applications of fish protein isolates in food and feed systems: a review. Journal of Food Science and Technology, https://doi.org/ 10.1007/s13197-019-03966-5

Shotton, R. (1997). Lanternfishes: a potential fishery in the northern Arabian Sea? In Review of the State of World Fishery Resources: Marine Fisheries. FAO Fisheries Circular, 920, FAO, Rome

St. John, M.A., Borja, A., Chust, G., Heath, M., Grigorov, I., Mariani, P., Martin, A.P., Santos, R.S. (2016). A dark hole in our understanding of marine ecosystems and their services: perspectives from the Mesopelagic Community. Frontiers in Marine Science, 3, 31 https://doi.org/10.3389/fmars.2016.00031

Staby, A., \& Salvanes, A.G.V. (2019). Mesopelagic Fish. In J. K., Cochran, H., Bokuniewicz, \& P., Yager, (Eds.), Encyclopedia of Ocean Sciences (3rd Edition). Academic Press, Volume 2, p 283-289

Teutscher, F. (2001). Options for utilization of lanternfish (Benthosema pterotum, Myctophidae) in the Gulf of Oman, Report of the Trilateral Workshop on Lanternfish in the Gulf of Oman, FAO Fisheries Report 665, FAO, Rome

Valinassab, T. (2005). Biomass distribution and pattern of myctophids in the Oman Sea. Iranian Journal of Fisheries Science, 2,101-110 https://doi.org/10.22092/IJFS.2018.114822

Valinassab, T., Pierce, G.J., \& Johannesson, K. (2007). Lanternfish (Benthosema petrotum) resources as a target for commercial exploitation in the Oman Sea. Journal of Applied Ichthyology, 23, 573-577 https://doi.org/10.1111/j.1439-0426.2007.01034.x

Wang, J.T. \& Chen, C.T. (2011). A review of lanternfoshes (Families: Myctophidae and Neoscopelidae) and their distribution around Taiwan and the Tungsha islands with notes on seventeen new records. Zoological Studies, 2, 103-126

Wilson, R.P. (2002). Amino acids and proteins. In J.E., Halver, \& R.W., Hardy, (Eds.), Fish nutrition. $3^{\text {rd }}$.Ed. New York: Academic Press. p.143-179 